\title{
Effect of Organic Coating Corrosion Inhibitor on Protection of Reinforced Mortar
}

\author{
Evgenia Voulgari'1, Aggeliki Zacharopoulou' ${ }^{1}$, Nikolaos Chousidis ${ }^{2}$, George Batis ${ }^{1}$ \\ ${ }^{1}$ Department of Chemical Engineering, National Technical University of Athens, Athens, Greece \\ ${ }^{2}$ Department of Civil and Environmental Engineering, University of Cyprus, Nicosia, Cyprus \\ Email:voulgariep@gmail.vom, azachar@chemeng.ntua.gr,chousidis.nikolaos@ucy.ac.cy,batis@chemeng.ntua.gr
}

How to cite this paper: Voulgari, E., Zacharopoulou, A., Chousidis, N. and Batis, G. (2019) Effect of Organic Coating Corrosion Inhibitor on Protection of Reinforced Mortar. Journal of Materials Science and Chemical Engineering, 7, 20-34.

https://doi.org/10.4236/msce.2019.71003

Received: June 12, 2018

Accepted: January 19, 2019

Published: January 22, 2019

Copyright () 2019 by authors and Scientific Research Publishing Inc. This work is licensed under the Creative Commons Attribution International License (CC BY 4.0).

http://creativecommons.org/licenses/by/4.0/

\section{Open Access}

\begin{abstract}
Corrosion of reinforced concrete is the most important cause of concrete structure deterioration. In the present study, the protective effect of the reinforcement mortars against corrosion is examined. In particular, the chloride penetration resistance on reinforced cement mortars using organic coating as additive containing was studied. The aforementioned additive consists of corrosion inhibitor for protection of steel rebars against pitting corrosion. For the experimental procedure, four (4) different types of reinforced mortars were prepared. The corrosion protection of the additive was evaluated by electrochemical methods, (linear polarization resistance, Half-cell Potential Resistance and Electrochemical Impedance Spectroscopy). In addition, the mass loss of steel rebars against time of partially immersed in $\mathrm{NaCl}$ solution was carried out in the lab. The experimental results showed that in all examined cases the organic coating provides anticorrosion protection on steel rebars against chlorides.
\end{abstract}

\section{Keywords}

Reinforcement Corrosion, Corrosion Inhibitors, Organic Coatings, Chloride Ions, Electrochemical Measurements, Mass Loss

\section{Introduction}

Reinforced concrete structures lately are facing the phenomenon of natural aging, mainly due to the reduced resistance of reinforced concrete caused by corrosion of steel reinforcement. Steel corrosion is generally considered as a complex phenomenon that is dependent on many factors.

Generally, reinforced concrete structures are very resistant to damage from physical and chemical-factors as well as from mechanical loads. A thin surface 
layer of hydrated iron oxide is created upon the reinforcement, which due to the high alkalinity $(\mathrm{pH}=12.5$ - 13.5) of the concrete leads to protect the reinforcement steel from corrosion [1]. However, the exposure of the reinforced concrete in a corrosive environment such as chloride ions $\left(\mathrm{Cl}^{-}\right)$or carbon dioxide $\left(\mathrm{CO}_{2}\right)$, may cause a decomposition/cracking of the passive film upon the steel surface and the corrosion of the steel reinforcement [2].

Chloride ions from de-icing salts and/or marine environments penetrate the concrete cover and they can reach the surface of the reinforcement steel [3], but the mechanism is not fully understood as the event occurs inside the concrete and the film is too thin to be examined.

When the ratio $\left[\mathrm{Cl}^{-}\right] /\left[\mathrm{OH}^{-}\right]$is bigger than 0.6 , chloride ions may penetrate concrete cover and build up over time until the concentration reaches a level sufficient to depassivate the steel [4]. After initiation of the corrosion process, the steel will begin corroding and setting up expansive stresses that will crack and spall the concrete cover [5] [6] which eventually result in progressive deterioration of the concrete.

For the effective protection of steel reinforcement in concrete structures, the most widely protective methods that can be used, are the following: cathodic protection, organic coatings, corrosion inhibitors-mineral additives such as pozzolans, silica fume etc. [7]. Corrosion inhibitors are organic or inorganic salts used as admixtures in concrete production in order to protect the steel rebars from corrosion; on the other hand, the inhibitors improve the chloride penetration resistance of concrete. A corrosion inhibitor can be defined [8] as "a chemical compound" added in adequate amounts to concrete prevents or delays the corrosion of embedded steel and has no adverse effect on its physical/mechanical properties. It is worth noting that these type of admixtures increase the consistency of the passive layer on the steel surface, creating a barrier film on the steel, blocking the ingress of chlorides and increasing the degree of chloride binding capacity of the concrete; the oxygen ingress can be also prevented using the corrosion inhibitors or blocking the ingress of oxygen.

It should be mentioned that corrosion inhibitors do not block the evolution of corrosion process, but they rather increase the time of the onset of corrosion and reduce its eventual rate [9]. The fact that corrosion inhibitors may not remain in the repair area, or that there is a potential for micro-cell corrosion development when they are used in a limited area long a continuous reinforcing bar, are some of the drawbacks of corrosion inhibiting admixtures.

In previous work [10], it has been proved that the organic coatings can also be used for the protection of the steel reinforcement, as they consist a barrier between the porous concrete structure and the corrosive environment and so they are widely used in concrete structures for protection.

The main objective of this study is the experimental study of the use of organic coating containing corrosion inhibitor to provide anticorrosion protection on the reinforcement steel. The use of such organic coating would reduce the cost of labor as a single job will be required. 
To evaluate the coating's protection, the specimens were partially immersed in a chloride solution simulated the marine environment. Electrochemical parameters such as corrosion rate (HCP), current (Icorr) and resistance (Rp) of the reinforcement steel embedded in mortar specimens have been evaluated against time of exposure in sodium chloride solution; electrochemical mass loss calculated by Faraday's law and mass loss of steel rebars obtained after breaking of mortars.

\section{Experimental}

The corrosion protection of organic coating additive with corrosion inhibitor was studied in four different groups; Steel rebars were cleaned with acetone, distilled water and water from the supply network and axially placed in the cylindrical mortars; the specimens were then partially immersed in $3.5 \mathrm{w} / \mathrm{t} \% \mathrm{NaCl}$ solution. The groups prepared in the lab were: 1) cement mortars with organic coating on their surface, 2) the coating was applied on the steel surface and 3) the coating was applied both on the surface of the mortar and the steel rebar.

In order to test the corrosion of reinforcement in concrete were used the following methods:

- Half-cell potential measurements of against time of exposure I chloride solution. $\mathrm{An} \mathrm{Ag} / \mathrm{AgCl}$ electrode (was used as reference in contact with the surface of each specimen.

- Polarization curves recording of steel rebars.

- Mass loss measurements of reinforcement steel.

\subsection{Material Selecting}

For the experimental study cement I $42.5 \mathrm{~N}$, calcareous fine aggregates ( 0 - 4 $\mathrm{mm}$ ) and water from the supplied network was used; the materials used are in agreement with ELOT 452, for the construction of the specimens. The ratio of the constituents was: cement: sand: water 1:3:0.5 $\left(489 \mathrm{~kg} / \mathrm{m}^{3}\right.$ cement: $1466 \mathrm{~kg} / \mathrm{m}^{3}$ sand: $245 \mathrm{~kg} / \mathrm{m}^{3}$ water).

The chemical composition of the cement is presented in Table 1 in which oxide values were tested by an XRD analysis, LOI values were tested according to ASTM D7348-13 "Standard Test Methods for Loss on Ignition (LOI) of Solid Combustion Residues" and Insoluble residue values were tested according to ASTM D3042-17 "Standard Test Methods for Insoluble Residue in Carbonate Aggregates".

Cylindrical steel rebars type Tempcore B500C with dimensions $100 \mathrm{~mm}$ height and $10 \mathrm{~mm}$ diameter were used. The chemical analysis of Steel reinforcement is represented in Table 2. Rebars were manufactured according to Greek specifications of Hellenic Organization for Standardization ELOT 1421-37 [11]. Figure 1 represents the reinforced cement mortars used in the present study.

The protective system used included two coatings:

- The first coating was a single-component colorless liquid that contained the 
Table 1. Chemical composition of cement used for specimens preparation.

\begin{tabular}{cc}
\hline Oxides & CEM I 42.5N \\
\hline $\mathrm{SiO}_{2}$ & 19.50 \\
$\mathrm{Al}_{2} \mathrm{O}_{3}$ & 4.80 \\
$\mathrm{Fe}_{2} \mathrm{O}_{3}$ & 3.60 \\
$\mathrm{CaO}$ & 63.50 \\
$\mathrm{MgO}$ & 3.40 \\
$\mathrm{~K}_{2} \mathrm{O}$ & 0.69 \\
$\mathrm{Na}_{2} \mathrm{O}$ & 0.22 \\
$\mathrm{SO}_{3}$ & 2.60 \\
$\mathrm{CaOf}$ & 1.00 \\
LOI & 3.49 \\
Insoluble residue & 0.20 \\
\hline
\end{tabular}

Table 2. Chemical analysis of steel reinforcement.

\begin{tabular}{ccccccc}
\hline & $\mathrm{Fe}$ & $\mathrm{C}$ & $\mathrm{S}$ & $\mathrm{P}$ & $\mathrm{N}$ & $\mathrm{Ceq}$ \\
\hline B500C Tempcore & $99.168 \%$ & $0.22 \%$ & $0.05 \%$ & $0.05 \%$ & $0.012 \%$ & $0.5 \%$ \\
\hline
\end{tabular}
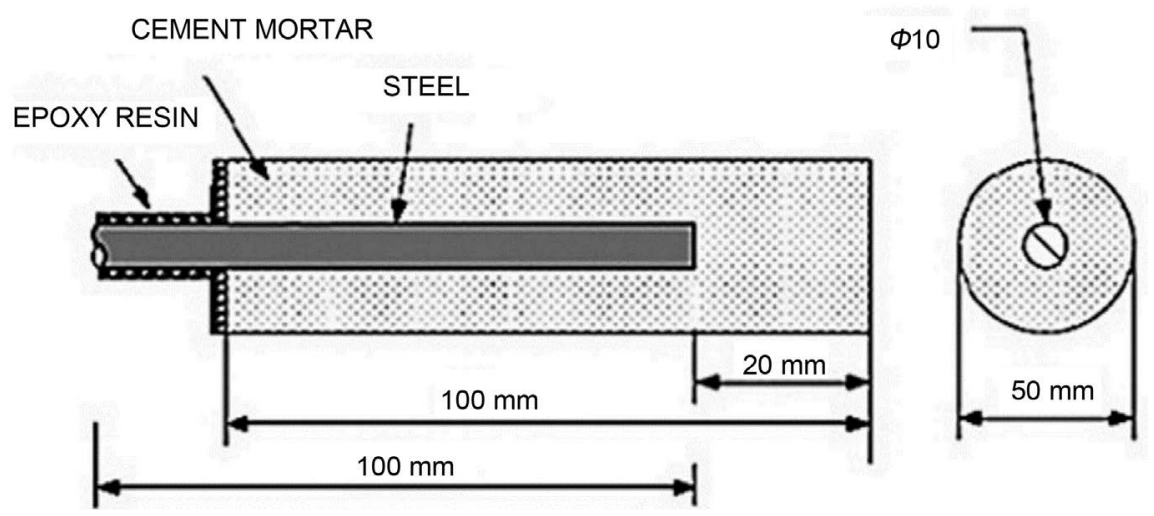

Figure 1. Schematic representation of the reinforced mortar specimen.

volatile corrosion inhibitor. The volatile corrosion inhibitor vapor and permeate the concrete as a gas and form a passive film on the corroded reinforcing steel (reference).

- The second coating is a single-component, clear, water based liquid. It has high alkalinity and encapsulates water-soluble chlorides, fills voids in the concrete and inhibits further penetration of moisture. It is applied as a second layer after the first coating.

Both coatings were applied using a brush on the dried surface of the specimens while the second coating was applied $24 \mathrm{~h}$ after the first layer.

\subsection{Specimens Preparation}

Four groups of specimens were constructed and each one of them consisted of 6 cylindrical specimens with a height of $100 \mathrm{~mm}$ and a diameter of $50 \mathrm{~mm}$. The 
steel rebars were cleaned before insertion into the mortars according to ISO/DIS 8407.3 and weighted to $0.1 \mathrm{mg}$ accuracy. For the electrochemical measurements, a copper wire was enwrapped to each steel rebar.

Organic coating was applied on the surface of the steel bars that are used for groups $\mathrm{B}$ and $\mathrm{C}$. The steel rebars were then embedded into the mortar; the space between the specimen base and the bottom of steel was constantly $20 \mathrm{~mm}$.

Organic coating was applied also on the external surface of specimens of groups A and C. Table 3 summarizes the four categories of specimens prepared for the experimental set-up.

\section{Experimental Set-Up}

\subsection{Half-Cell Potential Measurements (HCP)}

Half-cell potential measurements are the most widely used method of detection of corrosion of steel reinforcement in concrete [3]. The measurement of the corrosion potential of the steel versus a reference electrode provides information on the probability of corrosion in the concrete [12].

The Half-cell potential (Ecorr) shows only the tendency of steel for corrosion but does not reflect the corrosion rate of reinforcement. Corrosion rate of reinforcements is affected by a number of factors, which can be the diffusion of oxygen, the concrete's porosity and the presence of highly resistive layer [7]. Measurements of the electrochemical potential of the steel reinforcement were obtained with the use of a high-impedance voltammeter.

\subsection{Linear Polarization Resistance Technique (LPR)}

A Potensiostat/Galvanostat Model 263A from EG\&G Princeton Applied Research was used for the test with the associated software package in order to analyze the obtained data. The potential scan range was $\pm 10 \mathrm{mV}$ from OCP and the scan rate was $0.1 \mathrm{mV} / \mathrm{s}$. The experimental set-up was consisted of the steel rebars that represent the working electrode, an electrode $\mathrm{Ag} / \mathrm{AgCl}$ which represents the reference electrode and a carbon bar as a counter electrode (Figure 2).

Linear Polarization Resistance Technique is an electrochemical method of monitoring corrosion rate in real time. It is a rapid and non-destructive method. In LPR measurements the reinforcing steel is perturbed by a small amount of its

Table 3. Description of the four groups of cement mortars that were constructed.

\begin{tabular}{|c|c|}
\hline Group A & $\begin{array}{l}\text { Specimens in which a two layer organic coating that includes corrosion } \\
\text { inhibitor was applied on the external surface of mortar specimens }\end{array}$ \\
\hline Group B & $\begin{array}{l}\text { Specimens in which a two layer organic coating that includes corrosion } \\
\text { inhibitor was applied on the external surface of steel rebars }\end{array}$ \\
\hline Group C & $\begin{array}{c}\text { Specimens in which a two layer organic coating that includes corrosion } \\
\text { inhibitor was applied on the external surface of mortar specimens } \\
\text { and on the external surface of steel rebars }\end{array}$ \\
\hline Group D & Specimens without inhibitor application \\
\hline
\end{tabular}




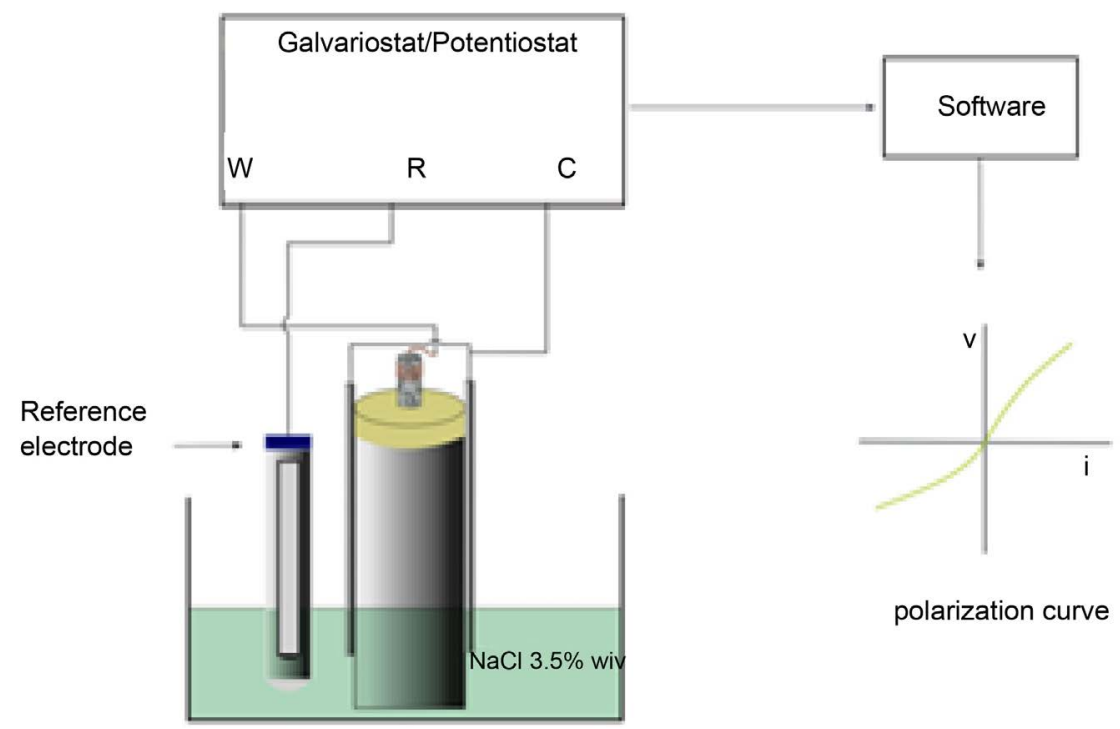

Figure 2. Schematic representation or experimental setup for polarization measurements.

equilibrium potential. This can be accomplished potentiostatically by changing the potential of the reinforcing steel by a fixed amount, $\Delta E$, and monitoring the current decay, $\Delta I$, after a fixed time [10].

Based on Stern-Geary method, the polarization resistance is calculated using Equation (1).

$$
R p=\frac{\Delta E}{\Delta I}
$$

From Equation (1) can be calculated the corrosion rate Icorr by the Equation (2):

$$
\text { Icorr }=\frac{\beta \alpha \cdot \beta c}{2.303(\beta \alpha+\beta c)}\left(\frac{1}{R p}\right)
$$

where $\beta a, \beta c$ are the anodic and the cathodic Tafel slopes, respectively.

Corrosion current density, icorr, is calculated by Equation (3), where $A$ is the surface area of steel that has been polarized.

$$
i c o r r=\frac{\text { Icorr }}{A}
$$

The mass loss is calculated by the Equation (4)

$$
\beta=\frac{I * M * t}{z * F}
$$

where $\beta$ is the mass loss of the steel rebar (g), $I$ is the corrosion rate (A), $M$ is the atomic mass of the metal ( $56 \mathrm{~g}$ for $\mathrm{Fe}$ ), $t$ is the time of exposure (s), $z$ is the ion chance ( $=2$ for $\mathrm{Fe} \rightarrow \mathrm{Fe}^{2+}+2 \mathrm{e}^{-}$), and $F$ is the Faraday's constant 96.500 $\left(\mathrm{A}^{*} \mathrm{~s}\right)$.

\subsection{Mass Loss of Steel Rebars}

Mortar specimens were broken at 12,18 and 24 months, in order to evaluate the 
corrosion from chloride ions. After re-dusting and cleaning, the final weight of the steel was obtained and the mass loss was calculated from the difference between its initial and the final weight at any age:

$$
\Delta M=M_{\text {initial }}-M_{\text {final }}
$$

where, $M_{\text {initial }}$ is the mass of steel at the beginning, $M_{\text {final }}$ is the mass after immersion in $\mathrm{NaCl} 3.5 \%$ w/t.

\subsection{Electrochemical Impedance Spectroscopy (EIS)}

Electrochemical impedance spectroscopy is a non-destructive method that can be used on materials in which the ionic conduction is prevalent on the electronic one; hence, EIS analyzes a lot of materials such as coatings, anodized films and corrosion inhibitors. The aforementioned method can provide detailed information of the systems that are under examination and parameters such as corrosion rate, electrochemical mechanisms and reaction kinetics [13].

Measurements are generally carried out using a conventional three electrode cell filled with the electrolytic solution which are the working electrode (the sample under the study), the counter electrode and the reference electrode (such as $\mathrm{Ag} / \mathrm{AgCl} / \mathrm{KCl}$ sat.).

A SI 1260 Impedance/Gain-phase Analyzer was used for the electrochemical impedance spectroscopy, which was acquired using the combination of a Potentiostat/ Galvanostat Model 263A from EG\&G Princeton Applied Research with a frequency response analyzer and the obtained date were analyzed with an associated software package.

\section{Results and Discussion}

\subsection{Corrosion Evaluation}

\subsubsection{Half-Cell Potential Measurements}

Figure 3 presents the average values of corrosion potential of six specimens versus time of exposure in $3.5 \mathrm{w} / \mathrm{t} \% \mathrm{NaCl}$ solution. From the results, it can be seen that the groups of specimens that contain corrosion inhibitor (Groups A, B,

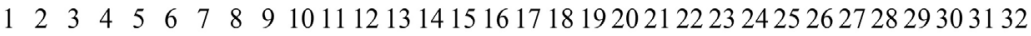

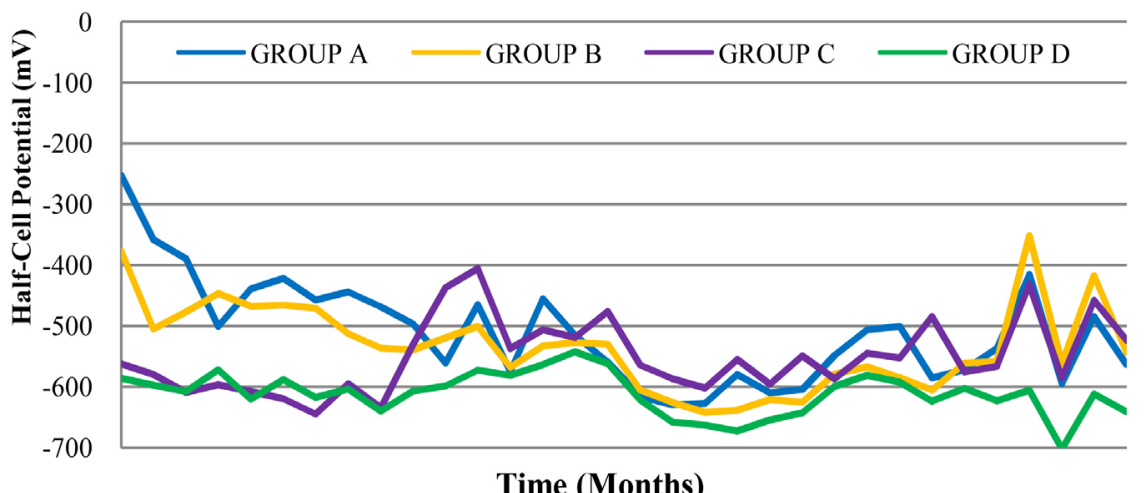

Figure 3. Half-Cell Potential versus time (months). 
C) seems to have higher values of potential than those of group D (without corrosion inhibitor). It is also obvious that the application of two layers organic coating on the surface of the mortar shift the half-cell potential to more electropositive value for the first 10 months in contrast with the using of the two layer organic coating on the surface of the steel rebar. From 11th month and then it is observed that the application of organic coating on the surface of the mortar and steel rebar shifts half-cell potential to electronegative values until the 26th month. It is remarkable that values of half-cell potential of the specimens with the application of the two layers organic coating, either on the surface of the mortar, either on the surface of the steel rebar, either on both, are more electropositive than the values of the specimens without the application of organic coating, for all the period of the experiment.

Table 4 shows the corrosion condition for the steel's corrosion potential according to ASTM C-867 criteria [14].

Figure 3 shows that at the end of the exposure period all specimens presented corrosion potential values that are indicative of severe corrosion, according to Table 3, as half-cell potential values vary from $-400 \mathrm{mV}$ to $-700 \mathrm{mV}$. It should be mentioned that Ecorr values show the corrosion tendency of steel reinforcement. The actual corrosion from the chloride effect is shown by corrosion current measurements [15].

\subsubsection{Electrochemical Mass Loss}

In order to make some conclusions for the corrosion condition of mortars for every group of specimens, the measurements of the mass loss are presented graphically versus time. In Figure 4 is presented the electrochemical mall loss of the steel rebar of the four groups of specimens versus the time they are expose to the corrosion environment. Generally from Figure 4 the electrochemical mass loss increases with time for all groups. The electrochemical mass loss of the specimens with two layer organic coating is lower than the electrochemical mass loss of the specimens without organic coating. After 19 months, the electrochemical mass loss is lower for the specimens that the organic coating was applied on the surface of the mortar and the steel rebar.

\subsubsection{Electrochemical Impedance Spectroscopy Measurements}

Electrochemical impedance measurements are usually made by imposing a small amplitude voltage or current to an electrochemical cell and then measuring the

Table 4. Corrosion potential and corrosion condition.

\begin{tabular}{cc}
\hline $\begin{array}{c}\text { Steel's corrosion versus Silver/silver chloride/1.0 } \\
\mathrm{M} \mathrm{KCl}(\mathrm{mV})\end{array}$ & Corrosion condition \\
\hline$>-100$ & Low (10\% risk of corrosion) \\
-100 to -250 & Intermediate corrosion risk \\
$<-250$ & High (90\% risk of corrosion) \\
$<-400$ & Severe corrosion \\
\hline
\end{tabular}




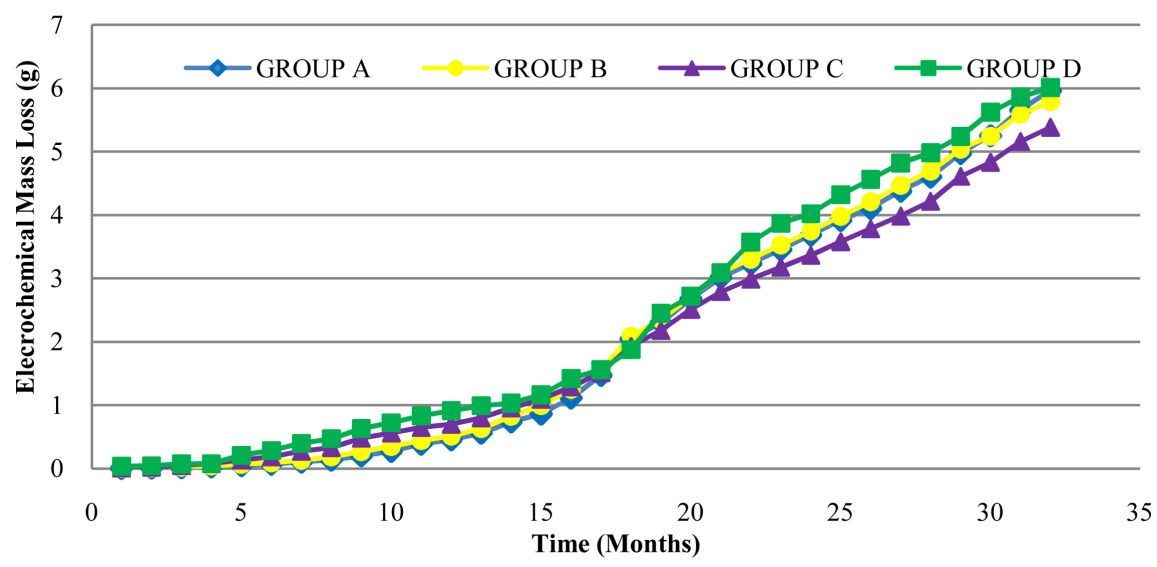

Figure 4. Electrochemical mass loss (g) versus time (months) for the 4 groups of specimens.

response sinusoidal current and voltage, respectively. Impedance is the measure of the resistance to current flow of the system. The impedance is represented as a complex number because it contains both magnitude and phase information. So it is composed of a real and an imaginary part. A Nyquist plot represents the impedance with the real part plotted on the $\mathrm{Z}$ axis and the imaginary part on the $\mathrm{Y}$ axis of the chart. Each point on the Nyquist plot is the impedance at one frequency [16].

The interpretation of impedance data is based on the use of an electrical equivalent circuit which is representative of the electrochemical process that occurs at the sample/electrolyte interface. In Figure 5 is represented the electrical equivalent circuit that describes the system.

The Nyquist plots for all the Groups of specimens after 10 months and 18 months in $3.5 \%$ w.t. $\mathrm{NaCl}$ solution are represented below.

In Table 5, the average values of the polarization residence (Rp) are shown.

From Nyquist plots (Figure 6 and Figure 7) and the polarization residence (Rp) (Table 5) it depicts that Rp for Group C is higher from the Rp of Groups A and $\mathrm{B}$. Additionally, group $\mathrm{D}$ that does not contain corrosion inhibitor, has the minimum values of polarization residence ( $\mathrm{Rp}$ ) after 10 and 18 months in the 3.5\% NaCl solution. These results show that Polarization Resistance for the Group of specimens in which the two layer organic coating was applied on the external surface of mortar specimens and on the external surface of steel rebars (Group C) is higher indicating lower susceptibility to corrosion.

\subsubsection{Mass Loss Results}

For the calculation of the mass loss of the steel rebar, specimens from all the groups were broken after 12, 18, 24 and 30 months of partially immersion in 3.5 wt $\% \mathrm{NaCl}$ solution. In Figure 8 is presented the mass loss of the steel rebars versus exposure time in the corrosion environment. For the results it can be observed that and the three systems protect specimens from corrosion. Also, at the first 12 months it is observed that the specimens in which the organic coating 


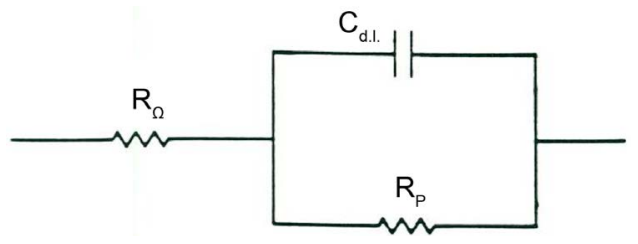

Figure 5. The electrical equivalent circuit that describes the system.

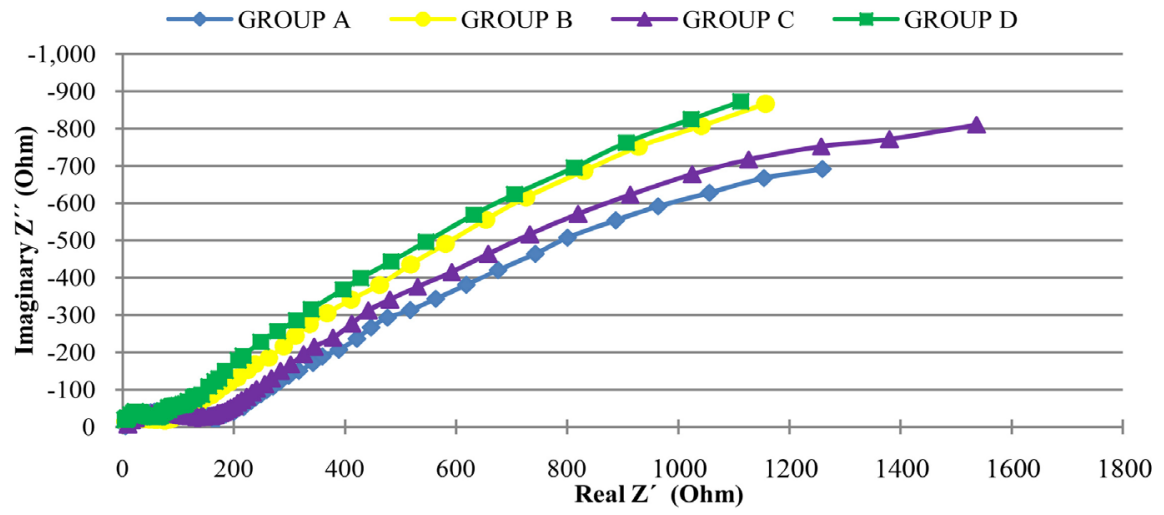

Figure 6. Nyquist plot for all groups after 10 months in $3.5 \%$ w.t. $\mathrm{NaCl}$ solution.

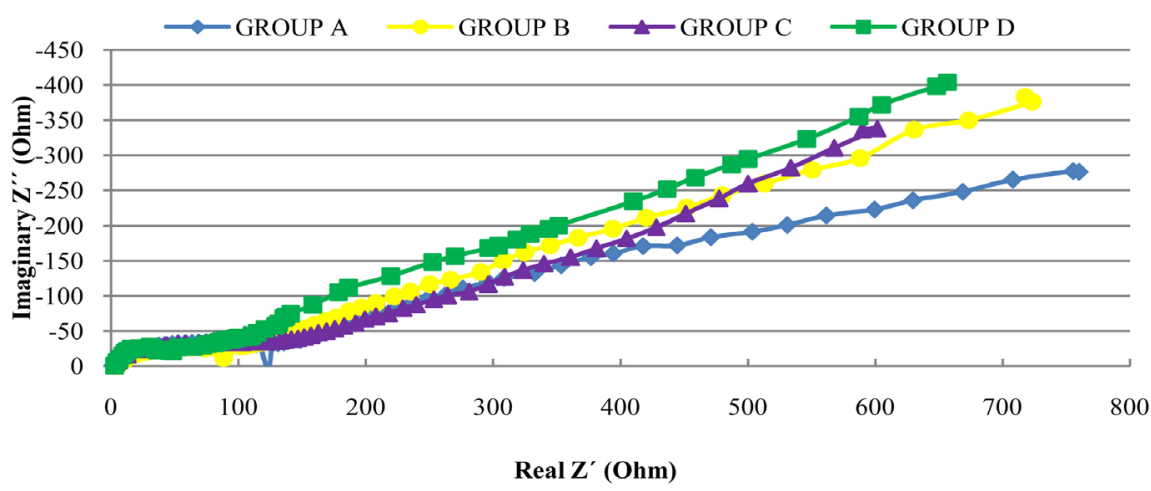

Figure 7. Nyquist plot for all Groups of specimens after 18 months in $3.5 \%$ w.t. $\mathrm{NaCl}$ solution.

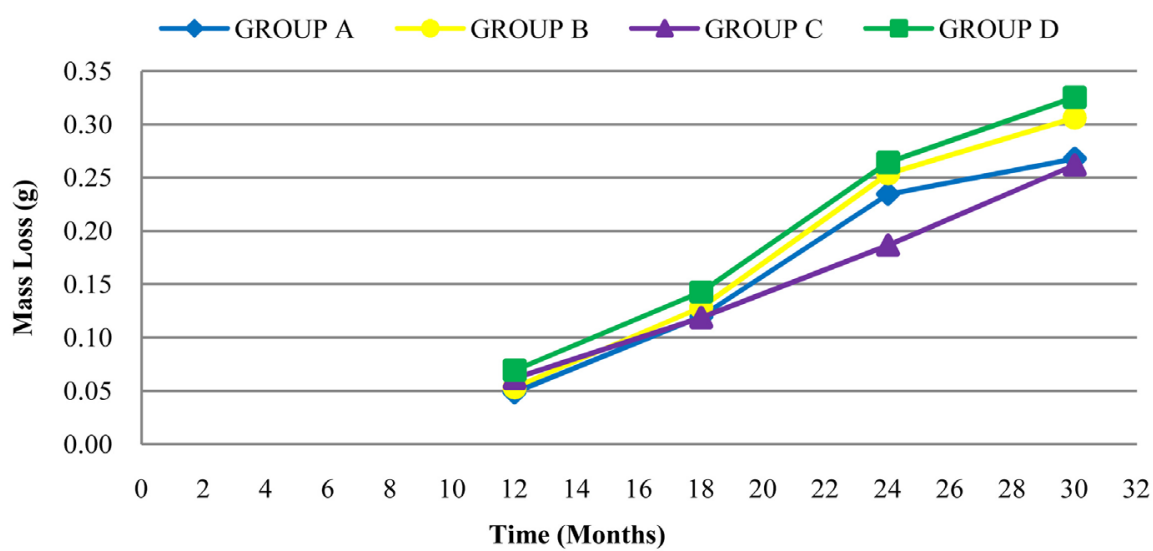

Figure 8. Mass loss (g) versus time (months) for the groups of specimens with and without organic coating. 
Table 5. Average values of Rp for the 4 Groups.

\begin{tabular}{ccc}
\hline & $\begin{array}{c}\text { Rp (Ohm) after 10 months in 3.5\% } \\
\text { w.t. } \mathrm{NaCl}\end{array}$ & $\begin{array}{c}\text { Rp (Ohm) after 18 months in 3.5\% } \\
\text { w.t. NaCl }\end{array}$ \\
\hline GROUP A & 155.60 & 130.00 \\
GROUP B & 104.40 & 132.20 \\
GROUP C & 169.20 & 159.40 \\
GROUP D & 100.50 & 126.30 \\
\hline
\end{tabular}

that contained corrosion inhibitor was applied on the surface of the mortar had smaller mass loss. After 12 months, the specimens in which the organic coating that contained corrosion inhibitor was applied on the surface of the mortar and steel rebar had smaller mass loss.

From Figure 8 is observed that specimens from Group C, where the two layer organic coating was applied both on the external of mortar and of steel bar, present better protection against corrosion, with a protection degree of $19 \%$.

\section{Discussion}

Based on the evaluation methods, it is observed that specimens in which the two layer organic coating was applied had corroded less than the specimens without organic coating. For the specimens which the two layer of organic coating has applied both to the surface and the steel rebar demonstrate the higher protection degree, (around 19\%). This degree of protection is not a satisfactory grade for an excellent corrosion inhibitor, given the fact that there are corrosion inhibitors with protection degree of $50 \%$. The small protection degree, it is possible due to the evaporation of the corrosion inhibitor, which leaves voids in the coating that contains it.

In previous work [17] the addition of organic corrosion inhibitors to mortar exposed in chlorine environment gave a protection rate of $25 \%$. Another work [18] carried out the combined corrosion inhibitor protection with an inorganic coating in a chlorine environment. Protection rates in this case were only $21 \%$ for the corrosion inhibitor and $26 \%$ for combined use of corrosion inhibitor and inorganic coating. The use of acrylic dispersion as a coating in the mortar provided 39\% protection. According to present study, the combined use of organic coating with volatile corrosion inhibitors in the organic coating on the surface on rebar's combines organic coating with volatile corrosion inhibitors on the surface of the mortar gave the maximum level of protection $19 \%$.

Analysis by scanning electron microscopy (SEM) was performed on two specimens: one from the group $\mathrm{C}$ and one of the group $\mathrm{D}$. On the specimens of group C, two-layer organic coating was applied on the external surface of mortar specimens and on the external surface of steel rebars. On the specimens of group $\mathrm{D}$, were not applied corrosion inhibitor, in order to investigate the bonding between inhibitor and the concrete.

Figure 9 illustrate the results of SEM analysis and Figure 10 the mapping of 


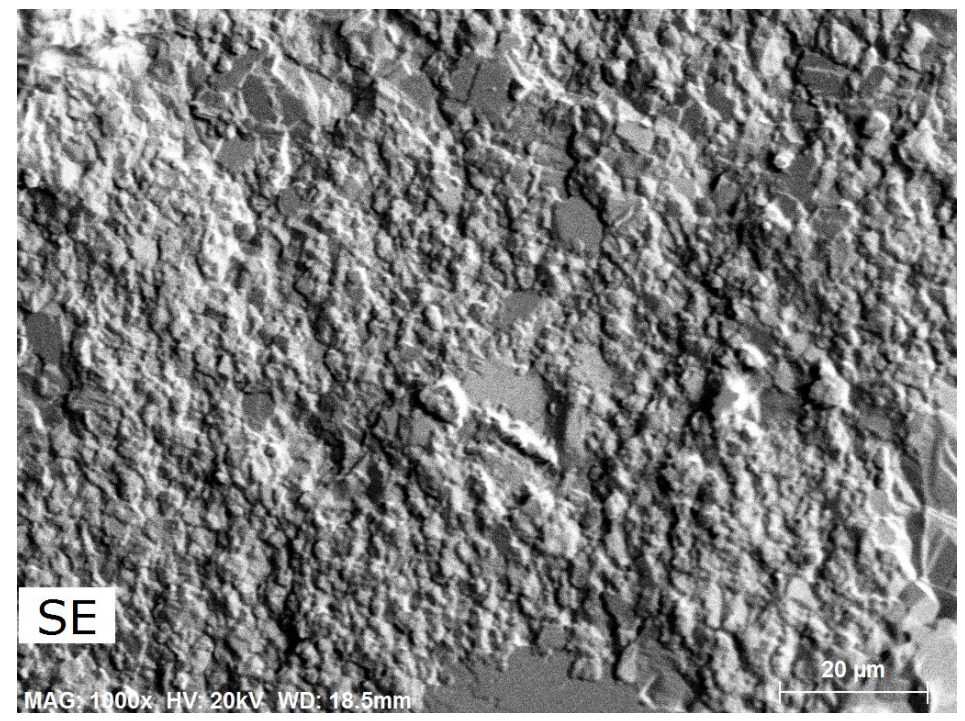

Figure 9. SEM analysis on specimen with corrosion inhibitor.

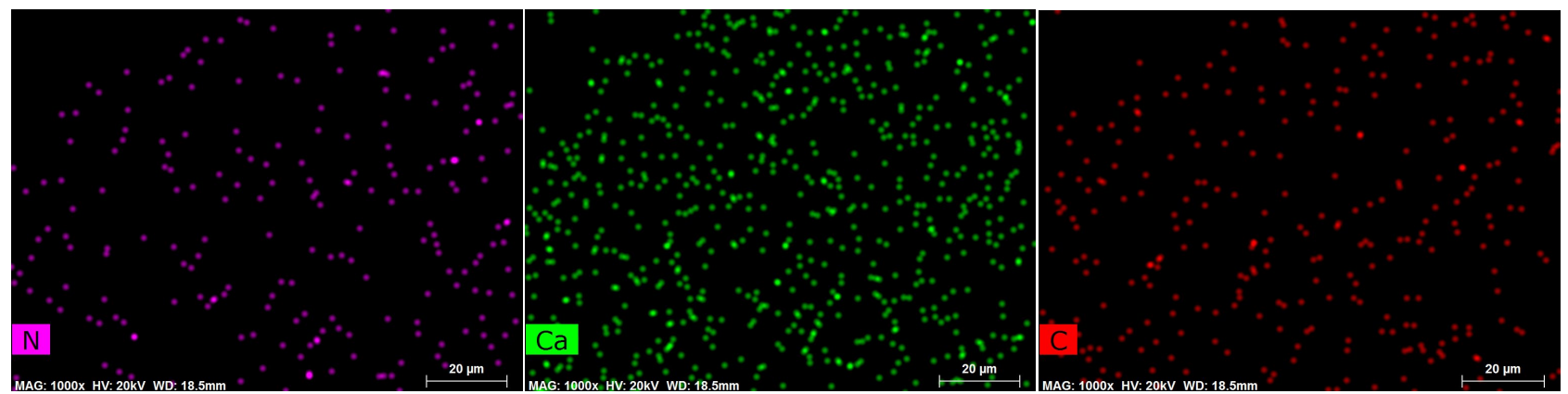

Figure 10. Nitrogen (N), Calcium (Ca) and Carbon (C) mapping on specimen with corrosion inhibitor.

three chemical elements $(\mathrm{N}, \mathrm{Ca}, \mathrm{C})$ observed on the specimen with corrosion inhibitor.

Respectively, Figure 11 show SEM analysis and Figure 12 the mapping of two chemical elements $(\mathrm{Ca}, \mathrm{C})$ observed on the specimen without corrosion inhibitor.

In specimen from Group D was observed absence of Nitrogen $(\mathrm{N})$, according to the mapping, which is expected, as it did not contain corrosion inhibitor.

From Figures 9-12, it depicts that corrosion inhibitor is distributed in the concrete and it is not concentrated at some point, as it should be happened, if the corrosion inhibitor had separated from the concrete. So the fact that corrosion rates seem to increase with time, even when the organic coating was applied to both the surface of the reinforcement and the surface of the mortar may be due to the small amount of the inhibitor that organic coating contains.

The idea of using an organic coating, with a volatile corrosion inhibitor to be applied to the surface of the mortar is attractive. Because, it achieves in one operation the merger of the two operations of applying the corrosion inhibitor and the organic coating to one. However, the protection rates of $19 \%$, even when applied to both the surface of the reinforcement and the surface of the mortar, 


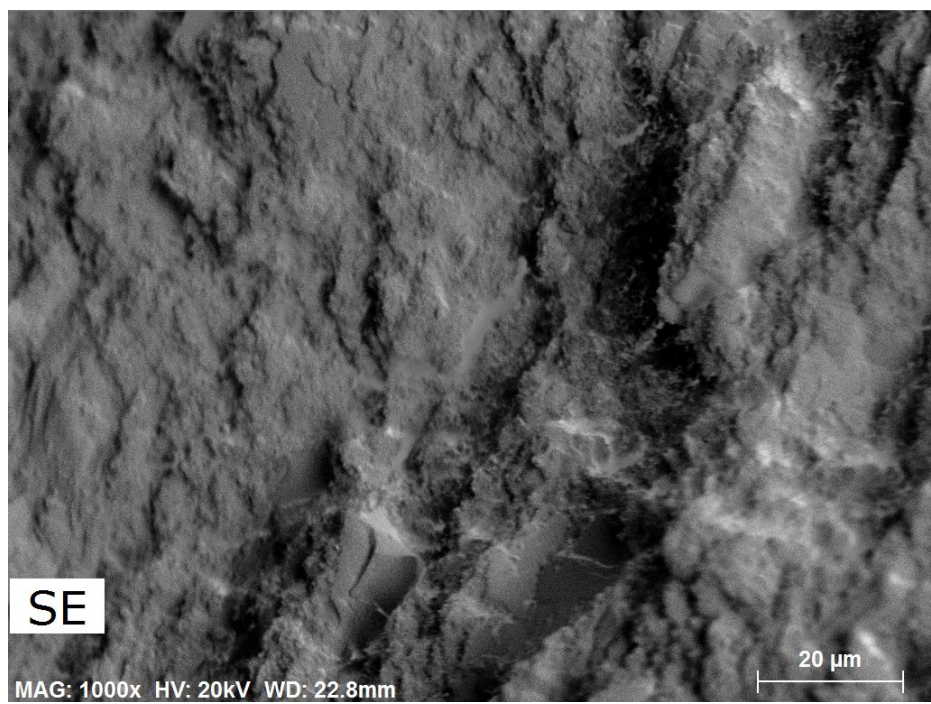

Figure 11. SEM analysis on specimen without corrosion inhibitor.
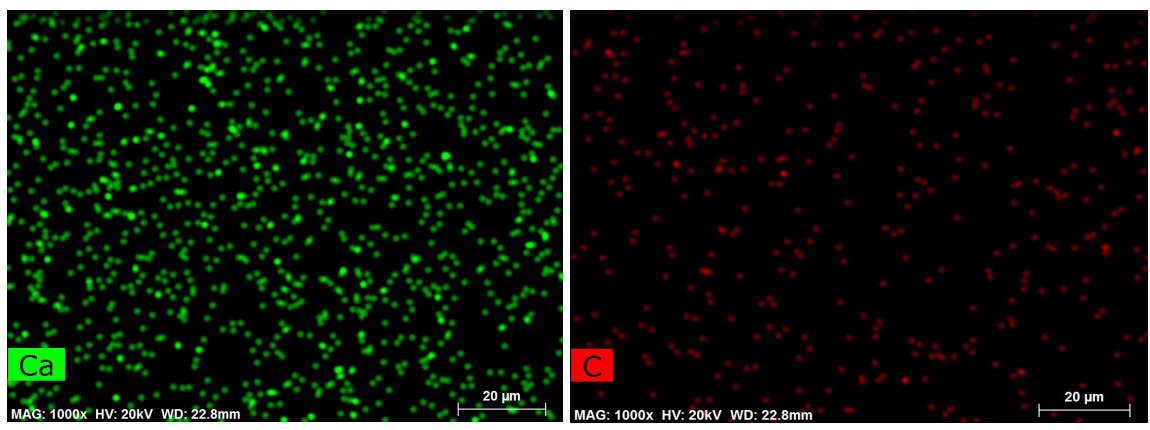

Figure 12. Calcium (Ca) and Carbon(C) mapping on specimen without corrosion inhibitor.

were poor. Therefore, the formation of the organic coating with volatile corrosion inhibitor should be re-examined.

\section{Conclusions}

In the present paper, four systems were studied regarding their protection level against corrosion by chloride ions. From the results of the measurements, the following can be drawn:

- The organic coating containing corrosion inhibitor provides anticorrosion protection on steel rebars in all cases.

- The system organic coating/corrosion inhibitor applied on the surface of the mortar and steel rebar appeared better behavior than the other systems.

- The optimum anticorrosion protection using the organic coating was $19 \%$.

The present research could be continued in order to optimize the composition of the organic coating to protect against corrosion of concrete reinforcements with possible improvement of the second layer of the organic coating, so that the corrosion inhibitor contained in the first layer does not vapor outwards. This will also increase corrosion inhibitor in the concrete. 


\section{Conflicts of Interest}

The authors declare no conflicts of interest regarding the publication of this paper.

\section{References}

[1] Kouloumbi, N. and Batis, G. (1992) Chloride Corrosion of Steel Rebars in Mortars with Fly Ash Admixtures. Cement and Concrete Composites, 14, 199-207. https://doi.org/10.1016/0958-9465(92)90014-M

[2] Zacharopoulou, A., Zacharopoulou, E. and Batis, G. (2014) Protection Systems for Reinforced Concrete with Corrosion Inhibitors. Open Journal of Metal, 4, 86-92. https://doi.org/10.4236/ojmetal.2014.44010

[3] Hanson, C.M., Poursaee, A. and Jaffer, S.J. (2012) Corrosion of Reinforcing Bars in Concrete. The Masterbuilder.

[4] Kouloumbi, N. and Batis, G. (1992) Chloride Corrosion of Steel Rebars in Mortars with Fly Ash Admixtures. Cement \& Concrete Composites, 14, 199-207. https://doi.org/10.1016/0958-9465(92)90014-M

[5] O’Reilly, M., Darwin, D., Browning, J., Xing, L., Lock Jr., C.E. and Virmani, Y.P. (2013) Effect of Corrosion Inhibitors on Concrete Pore Solution Composition and Corrosion Resistance. ACI Materials Journal, 110-M53.

[6] Song, H.-W. and Saraswathy, V. (2007) Corrosion Monitoring of Reinforced Concrete Structures-A Review. International Journal of Electrochemical Science, 2, $1-28$.

[7] Chousidis, N., Rakanta, E., Ioannou, I. and Batis, G. (2015) Anticorrosive Effect of Electrochemical Manganese Dioxide By-Products in Reinforced Concrete. Journal of Materials Science and Chemical Engineering, 3, 12. https://doi.org/10.4236/msce.2015.35002

[8] Hanson, C.M., Mammoliti, L. and Hope, B.B. (1998). Corrosion Inhibitors in Concrete-Part I: The Principles. Cement and Concrete Research, 28, 1775-1781. https://doi.org/10.1016/S0008-8846(98)00142-2

[9] Batis, G. and Rakanta, E. (2001) Effects of Migrating Corrosion Inhibitors on Reinforced Lightweight and Common Mortars. 2nd International Congress on Studies in Ancient Structures, Istanbul, 2, 560-570.

[10] Zafeiropoulou, T., Rakanta, E. and Batis, G. (2013) Carbonation Resistance and Anticorrosive Properties of Organic Coatings for Concrete Structures. Journal of Surface Engineered Materials and Advanced Technology, 3, 67-74. https://doi.org/10.4236/jsemat.2013.31A010

[11] ELOT 142-37, Hellenic Organization of Standardization, Athens.

[12] Broomfield, J.P. (2006) Corrosion of Steel in Concrete: Understanding, Investigation and Repair. 2nd Edition, Taylor \& Francis, 14.

[13] Hamby, A.S., El-Shenawy, E. and El-Bitar, T. (2006) Electrochemical Impedance Spectroscopy Study of the Corrosion Behavior of Some Niobium Bearing Stainless Steels in 3.5\% NaCl. International Journal of Electrochemical Science, 171-180.

[14] Broomfield, J.P. (2006) Corrosion of Steel in Concrete: Understanding, Investigation and Repair. 2nd Edition, Taylor \& Francis, 49.

[15] Chousidis, N., Rakanta, E., Ioannou, I. and Batis, G. (2016) Influence of Iron Mill Scale Additive on the Physico-Mechanical Eproperties and Chloride Penetration Resistance of Concrete. Advances in Cement Research, 28, 389-402. 
https://doi.org/10.1680/jadcr.15.00129

[16] Macdonald, D.D., El-Tantawy, Y.A., Rocha-Filho, R.C. and Urquidi-Macdonald, M. (1994) Evaluation of Electrochemical Impedance Techniques for Detecting Corrosion on Rebar in Reinforced Concrete. Strategic Highway Research Program, National Research Council, Washington.

[17] Batis, G., Routoulas, A. and Rakanta, E. (2003) Effects of Migrating Inhibitors on Corrosion of Reinforcing Steel Covered with Repair Mortar. Cement and Concrete Composites, 25, 109-115. https://doi.org/10.1016/S0958-9465(01)00047-6

[18] Batis, G., Pantazopoulou, P. and Routoulas, A. (2003) Corrosion Protection Investigation of Reinforcement by Inorganic Coating in the Presence of AlkanolamineBased Inhibitor. Cement and Concrete Composites, 25, 371-377.

https://doi.org/10.1016/S0958-9465(02)00061-6 